\title{
Students as change partners in the School of Literature and Languages at the University of Reading
}

Article

Published Version

Creative Commons: Attribution-Noncommercial-No Derivative Works 4.0

Open access

Becker, L., Collier, J. and Setter, J. (2018) Students as change partners in the School of Literature and Languages at the University of Reading. The Journal of Educational Innovation, Partnership and Change, 4 (1). ISSN 2055-4990 doi: https://doi.org/10.21100/jeipc.v4i1.712 Available at https://centaur.reading.ac.uk/75675/

It is advisable to refer to the publisher's version if you intend to cite from the work. See Guidance on citing.

Identification Number/DOI: https://doi.org/10.21100/jeipc.v4i1.712 <https://doi.org/10.21100/jeipc.v4i1.712>

Publisher: Educational Development Unit, University of Greenwich

All outputs in CentAUR are protected by Intellectual Property Rights law, including copyright law. Copyright and IPR is retained by the creators or other copyright holders. Terms and conditions for use of this material are defined in the End User Agreement.

www.reading.ac.uk/centaur 


\section{CentAUR}

Central Archive at the University of Reading

Reading's research outputs online 


\title{
Students as change partners in the School of Literature and Languages at the University of Reading
}

\author{
Lucinda Becker, Joy Collier, Jane Setter \\ University of Reading
}

\section{Introduction}

The pedagogic landscape in Higher Education (HE) has certainly witnessed change in recent years and involving students as partners in aspects of degree-programme development is part of that change (Lowe and Dunne, 2017). Darling-Hammond (2009) described how educational systems internationally are changing priorities, to enable students to "cope with complexity, use new technologies, and work cooperatively to frame and solve novel problems" (op.cit., p. 45). Zhao (2011) asserts that it is vital to engage students as partners in change, giving them an active hand in programme design, to enable them to develop into creative individuals who leave education with much more than just an academic qualification; it is an "authentic way to develop professional skills" (Giles, Martin, Bryce and Hendry, 2004, p. 681), as well as an opportunity to develop a positive and autonomous approach to learning that will be long-lasting and productive. This case study involved students working cooperatively with each other and with staff in a school of literature and languages. Together, we redesigned a new module aimed at developing students' understanding of the demands of university-level study and writing and supporting them in their transition from sixth form to HE.

\section{Background and context}

This is one example from over fifty staff-student collaborative projects carried out at the University of Reading over the past four years, under the PLanT (Partnerships in Learning and Teaching) initiative - a joint venture with Reading University Students' Union (RUSU). As part of this scheme, dedicated teaching and learning funds are now ring-fenced each year to support the creative efforts of undergraduates and postgraduates working together with academics to enhance curricula. The journey to this point has, at times, been challenging and uncertain. Twenty years ago, student engagement at Reading could be defined as the level of attendance or 'intellectual presence' of students at teaching sessions. Student feedback on modules was reliably generated by prescribed module evaluation forms with limited appreciation of the qualitative richness that more authentic student contributions might offer.

A step change in our understanding of the value of the student voice occurred in 2008, when the University embedded what was known as the 'Pathfinder' process into the Periodic Review cycle in response to a Higher Education Academy (HEA)-led initiative. At the time, this was the primary means by which Schools and Departments were able to engage in the process of quality review of their programmes. As part of this initiative, dedicated School awaydays were carefully tailored to the teaching and learning (T\&L) priorities identified by students in both survey- and focus-group feedback. These events enabled staff to address the concerns of students in a developmental, forward-looking way and, as a result, Periodic Review became about quality enhancement as well as quality assurance. 


\section{Case Studies}

Despite its benefits, one significant drawback of Pathfinder was its emphasis on feedback rather than dialogue, with staff taking the lead in the interpretation of student data and therefore of its meaning for T\&L enhancement. However, Pathfinder (and the valuable insights it afforded into the reality of what students were experiencing) was a catalyst for change at a deeper level in the University mindset. The positioning of students in relation to their educational experiences became more one of autonomous contributor than of passive bystander; this was reflected in the language of the Reading Student Charter, which states "The University expects students to...be active partners in shaping their experience of HE" (The Reading Student Charter, 2012).

On the back of the launch of the Charter and two high-profile University-wide events addressing the 'students as partners' philosophy (Cook-Sather et al., 2014) and led by Cathy Bovill and Elisabeth Dunne - a successful bid was made to the University's Teaching and Learning Development Fund for the establishment of a 'Partnerships in Learning and Teaching (PLanT)' scheme. The scheme offers funding (up to £500) for small-scale projects in which students and staff work in partnership to develop T\&L in their discipline, often in response to student feedback. The selection panel is chaired by a Teaching and Learning Dean and includes members of the Academic Development Team and the RUSU Education Officer. A key criterion for selection is the extent to which there is an active partnership between students and staff throughout the project, with students' being involved in both the design and delivery of the project. Following a pilot with two projects in 2012/13, the PLanT scheme is now embedded in the University's annual offering of funding to support T\&L innovation; applications have grown from seven in 2013/14 to eighteen in 2016/17, reflecting the growing appetite for partnership across the institution.

\section{Project methodology}

When designing the first-year module 'Techniques and Skills for Applied Linguistics' (LS1TAL), the programme team on the BA English Language and combinations wanted student input to co-develop the module while it was running in 2014/15 - that is, while they were experiencing it. Four students and the staff teaching on it won PLanT funding to review the module in real time and to work to improve its usefulness, efficacy and relevance. As one of the students was from overseas, it was very interesting to see her perspective. As with many other UK universities, Reading is interested in diversity of all kinds; having an overseas student on the project enabled the programme team to take into account issues which might not otherwise have arisen.

LS1TAL is a 'bring your own device' (BYOD) module which includes elements of academic writing, transition to $\mathrm{HE}$, online footprint and branding, plagiarism and using the online submission tool Turnitin effectively, working in groups, library skills, presentation skills, thinking about careers, and being a global student. When the module was proposed, the Teaching and Learning Dean for Arts, Humanities and Social Sciences described it as 'very well-designed' and subsequently asked whether students were enjoying it. In fact, students had difficulty seeing the relevance of the module, felt that some areas had been covered at school (e.g., online safety and netiquette; plagiarism) and that there were too many sessions on transition to HE.

Once funding had been won early in academic year 2014/15, the student-staff team held 'brainstorming' sessions over four working lunchtimes from December to May, both to reflect 


\section{Case Studies}

and to suggest ways to improve the module. At first, the students were reticent about making suggestions (and eating the food!) but, when they realised how much their opinions and evaluations of the content and teaching approach were valued by the staff and that the intention was to make effective changes to support students' learning based on their feedback and recommendations, they gained confidence and were able to speak freely.

Reading has two teaching terms of eleven weeks, with ten teaching weeks and a break for academic-related activities in week six of each term. The team broke the module down into four parts, corresponding with teaching terms and mid-term activities, and looked mainly at the following:

- $\quad$ Did students feel the lectures had been supportive of their transition to HE, including academic, social and wellbeing issues?

- Had lectures introduced students to topics which were similar or different from what they had learnt at school?

- If similar, had these lectures added anything by developing knowledge and understanding, or simply re-iterated material already covered?

- If different, had the lecture brought something valuable to the student experience and knowledge base?

- Was there anything missing from these lectures which students wanted to know about in their first year (and was suitable as a topic in a series of academic lectures)?

- Was there too much or too little of any one topic?

- Did the supporting seminars help students develop their knowledge and skills?

- Did lectures and seminars do this in a way which addressed issues of diversity and inclusivity?

- Were seminar activities interactive enough?

- Did seminars make good use of 'bring your own device' (BYOD)?

The lead staff member made notes following each meeting and circulated these to students for comments prior to the next meeting.

Finally, the students were supported in re-drafting the entire module. This was more of a challenge than the students had originally realised, because - as well as academic considerations - there are constraints in the pattern of seminar sessions for this module and the availability of some external contributors. The team took the then current schedule of lectures and seminars, tore it apart based on discussion and on student module evaluation and pieced it back together over a series of weeks in the summer term. This was all done by email correspondence, as students were now either taking exams or had begun summer jobs and were not available to meet face to face.

\section{Project outcomes}

Success was measured in two ways: 1) considering how well student partners felt the module had been changed, within the confines of the overall aims and objectives, to suit student needs better; and 2) looking at the comments of students taking the module the following year. Student partners were satisfied that the aims and objectives were still met, now with greater focus and more consideration of: how students learn; diversity and equality of opportunity; relevance to the wider context outside academia; the appropriateness of the methods for the teaching and learning of this particular subject matter. There is a re-focused 


\section{Case Studies}

use of technology-enhanced learning (TEL) techniques, including writing for blogs, constructing a Linkedln page and learning how to produce 'how-to' videos. Students taking the module the following year commented favourably on the use of technology, particularly BYOD approaches, which they thought were integrated well to support their learning. Other changes that were made included the introduction of sessions on student wellbeing and mental health, more sessions on aspects of academic writing, fewer on transition to HE and the addition of lectures that are student-led. For example, 'If I knew then what I know now...' aims to help students understand the usefulness of LS1TAL by bringing back students and alumni from earlier cohorts to make connections between what they do on the module and how it supports their learning and development as academic individuals.

Having student partners more in control of the content gave them a better understanding of the opportunities, requirements and constraints of working in an academic environment and what university education sets out to achieve. They felt that they had been supported in the development of their own professional and academic skills through this process. Student lead Rebecca Greenbank (BA English Language and Literature) writes about her experience as follows:

"The PLanT meetings arranged by a group of students and staff including myself
and Jane have been thoroughly rewarding this year. Taking part in module
reviews and improvement made me value the work that goes into our teaching
and learning, and also led me to reflect on my own progress. The group
discussions also gave me confidence to be honest and offer suggestions which
not only benefitted me, but other students too. As an academic person, I feel
these skills are extremely useful and have been beneficial to my professional
development. I am now more confident in speaking out if I feel things could be
changed to benefit my learning or the learning of others. Furthermore, in a
professional context I am now much more proactive in voicing my opinions and
being able to both lead and contribute in discussions. Jane was crucial to this
development as she organised the meetings well and kept us all informed, and
encouraged us to be honest. She recorded all of our opinions and made sure that
the changes we suggested were incorporated in some form or another. Overall, I
loved the experience that the PLanT scheme provided for me, and will use the
skills I have gained as I progress into my second year at university and into the
professional world of work."

Rebecca went on to present, together with other staff and students on the PLanT initiative, at the Researching, Advancing and Inspiring Student Engagement (RAISE) conference in 2016, thus feeding back on this project into the national learning landscape. She subsequently became an assistant student editor on the RAISE journal.

The students in this case study are change partners (Zhao, 2011) and University T\&L practice has developed through our involvement with PLanT to ensure that the student voice is nurtured, heard and more actively incorporated across the University in programme and module development.

Involvement in this and other PLanT initiatives has also supported staff development, the impact being that other staff across the University have been encouraged to apply for PLanT funding, with benefits for their own professional development. The University has an annual 


\section{Case Studies}

PLanT showcase to disseminate good and innovative practice. A colleague who bid successfully for PLanT funding writes:

"Through this PLanT scheme, my student partners were invited to speak at a University/RUSU event including the Pro-Vice Chancellor of Teaching and Learning, which greatly boosted the students' own capacities for public speaking, and built their transferable skills using TEL. Further, the PLanT award was the basis for the university to nominate me for an inaugural JISC Institutional Change Leader training qualification, helping my own professional development and improving my capacities to use TEL in my learning. I wouldn't have done any of this without Jane's leadership and support."

\section{Evaluation and lessons learned}

Over time, it has become clear that PLanT projects are most meaningful if they are based on sound partnership principles. To establish these, colleagues are encouraged to address a set of fundamental questions at the inception of a project:

- Is there a genuine, and identifiable, need for change?

- What would students bring that an academic cannot contribute so effectively to the project?

- Will the students be able to own the project?

- Will the project have tangible, or readily identifiable, outcomes?

- Will the project have impact and will it be scalable and/or transferable?

The first of these questions is perhaps the most surprising. There is, of course, always a need for change: education by its very nature is both transformative and being transformed. However, the question is relevant in this context because it ensures that partnership projects have a purpose beyond the regular adjustments that academics already make to teaching on a day-by-day basis. To call on the time and effort of students for work that might last over several months, a project must make change that is necessary and efficacious.

The questions concerning what students can offer to the project and how they might take a leadership role are often vexed for the academic involved. It is all too easy to become excited about an idea for innovation and to ask students to get involved, only to forge ahead without really engaging with the students in an authentic partnership (Delpish et al., 2010). PLanT projects go beyond the normal practices of asking student representatives to attend meetings or inviting students to share their views in focus groups; they are based on a clear identification of both why and how student partners can best be involved. Academics know their own strengths and interests as educators and they also see the value of the student voice; they are now also coming to recognise that there are areas where students might simply know better than the academic. In the project discussed here, for example, the student evaluation forms would have highlighted a problem, but the students, not the academic, were in the best position to explore ways to overcome the learning hurdles that had been identified. In PLanT projects the academic is often largely in control at the outset, moving on to relinquish that position to students during the project, acting as a consultant but not necessarily being involved in all of the activities. The academic then needs to be ready to take a more active or leading role in the final stages, as plans are finalised concerning the 


\section{Case Studies}

action to be taken and the ways in which the results of the process can be fed into the wider learning landscape of a department, school or the university as a whole.

When applying for PLanT funding, the proposers (this will usually be an academic and a student partner) need to be clear about what will produced by the end of the period of activity. This could be a new set of teaching and learning resources or a redesigned module or a new way to assess learning. It could also be a longer-term partnership plan, in which students might be involved in teaching, learning or assessment as an integral part of a module or programme (a new form of peer-assisted learning, for example, or independent study groups working within guidelines designed in partnership). Although these outcomes are always identified at the outset, one of the most gratifying aspect of this scheme is the way in which, if there is genuine partnership, the outcomes tend to multiply and diversify.

Once a project takes off, students often identify a plethora of other possible options, some of which could fit the project aims much better than the outcomes that were initially identified in the proposal. Some flexibility, in the early stages of a project, regarding outcomes is therefore needed, as is the steady hand of the academic, allowing students to explore exciting innovations, while also helping to set gentle limits that guarantee success. The teaching expertise of the academic, in knowing what is achievable, is essential, and works in tandem with the learning experience of the students. It is pleasing to see how often this learning experience develops into real learning expertise by the end of these projects.

Although bids for funding are not assessed principally on transferability or scalability, such considerations are most usually factored into the project design and students are involved in the thinking around how this might be achieved as each piece of work develops. Beyond the immediate and intended impact of each project, the long-term impact of the PLanT scheme will continue to grow each year in ways that might not have been anticipated. The aims and outcomes of each project are recorded on the University of Reading's online T\&L Exchange, allowing for the sharing of ideas and best practice. PLanT projects give students the chance to explore 'the other side' of the teaching and learning matrix and to make valuable contributions to the experience of fellow learners. For academics, the PLanT scheme is transformative, as students become recognised not just as learners, but also as partners in the creation of learning.

\section{Reference list}

Cook-Sather, A., Bovill, C. and Felten, P. (2014) Engaging students as partners in teaching and learning. A guide for faculty. San Francisco: Jossey-Bass.

Darling-Hammond, L. (2009) 'Teaching and change wars: the professionalism hypothesis.' In: Fullan, M. and Hargreaves, A. (eds.), Change wars. Bloomington: Solution Tree Press, 45-68.

Delpish, A., Darby, A., Holmes, A., Knight-McKenna, M., Mihans, R., King, C. and Felten, P. (2010) 'Equalizing student voices: Student-faculty partnership in course design.' In: Werder, C. and Otis, M.M. (eds.), Engaging student voices in the study of teaching and learning. Virginia: Stylus Publishing.

Giles, A., Martin, S.C., Bryce, D., and Hendry, G.D. (2004) 'Students as partners in evaluation: Student and teacher perspectives.' Assessment \& Evaluation in Higher 


\section{Case Studies}

Education 29(6), 681-685. Available at:

https://www.researchgate.net/profile/Deborah Bryce/publication/228703992 Students as p artners in evaluation Student and teacher perspectives/links/5429f0240cf277d58e8701b d/Students-as-partners-in-evaluation-Student-and-teacher-perspectives.pdf (Accessed: 8 March 2018).

Lowe, T. and Dunne, E. (2017) 'Setting the scene for the REACT programme: aims, challenges and the way ahead.' Journal of Educational Innovation, Partnership and Change, 3(1), 24-39. Available at:

https://journals.gre.ac.uk/index.php/studentchangeagents/article/view/678 (Accessed: 8 March 2018).

RAISE: Student engagement in higher education journal. ISSN 2399-1836. Available at: https://journals.gre.ac.uk/index.php/raise (Accessed: 30 January 2018).

T\&L Exchange. Available at: https://blogs.reading.ac.uk/t-and-l-exchange/ (Accessed: 19 October 2017).

Turnitin. Available at: http://www.turnitinuk.com/ (Accessed: 7 February 2018).

The Reading Student Charter, (2012) Available at:

http://www.reading.ac.uk/internal/student/OnlineStudentHandbook/osh-student-charter.aspx (Accessed: 5 October 2017).

Zhao, Y. (2011) 'Students as change partners: A proposal for educational change in the age of globalization.' Journal of Educational Change 12(2), 267-279. Available at:

https://link.springer.com/article/10.1007/s10833-011-9159-9 (Accessed: 8 March 2018). 